\title{
Rapid assessment of protection and ecological effectiveness of the Spanish Fishing Reserve Network
}

\author{
David Rodríguez-Rodríguez ${ }^{\mathrm{a}, \mathrm{b}}$ \\ ${ }^{a}$ Institute of Economy, Geography and Demography, Spanish National Research Council (IEGD-CSIC), Associated Unit \\ GEOLAB. C/Albasanz, 26-28; 28037, Madrid, Spain. \\ ${ }^{b}$ University of Malaga, Andalucía Tech, European Topic Centre-Universidad of Malaga. Campus de Teatinos s/n, 29010 \\ Malaga, Spain. \\ E-mail addresses: david.rodriguez@csic.es, davidrr@uma.es, davidrgrg@ yahoo.es. \\ https://doi.org./10.1016/.j.marpol.2018.01.009
}

Keywords: Marine protected area; legal designation; management effort; performance; marine reserve

Abstract: $\quad$ Fishing Reserves (FRs) are primarily designated for the enhancement of local fisheries and, secondarily, for biodiversity conservation. In Spain, FRs are considered marine protected areas (MPAs) and included in the country's MPA network. MPAs' ecological effectiveness is linked to a number of legal, managerial and biophysical factors. With the amount of MPA area rapidly rising and conservation funds largely stagnant or decreasing, rapid, cost-effective MPA assessment techniques are becoming increasingly useful to verify fulfillment of global conservation targets and ascertain potential conservation effectiveness. Here, a rapid MPA protection assessment framework and one MPA ecological effectiveness framework were applied to the Spanish Network of 10 FRs (FRN): the MaPAF and NEOLI frameworks. The FRN was moderately legally protected, with over $50.5 \%$ of its area having three or more overlapping legal designations, but only $3.8 \%$ of the FRN's area being no-take. All FRs had management plans and active surveillance. According to MaPAF, Columbretes FR was the most highly legally protected whereas Cabo de Palos was the FR with the greatest managerial effort. Both rank highest in protection. In contrast, Masía Blanca FR and Alborán FR were the least legally protected whereas Alborán FR and Graciosa FR were the least managerially protected FRs of the FRN and rank the lowest in protection, respectively. According to the NEOLI framework, Columbretes would also be the most effective FR whereas Masía Blanca FR would be the least ecologically effective. These results can help to spur and better allocate conservation efforts across the fastly growing Spanish MPA network.

\section{Introduction}

FRs are one type of spatial protection measure of the seas aimed at enhancing fishing resources for sustainable fishing activities. As a result of the legal and managerial protection FRs are afforded, they also act as de facto MPAs by helping to conserve valuable biodiversity within their borders. International guidelines recommend not considering FRs as MPAs because their main aim is not biodiversity conservation, but as Other Effective Area-Based Conservation Measures (OEABCMs; Day et al., 2012). Both MPAs and OEABCMs should contribute to globally accepted targets to conserve at least $10 \%$ of coastal and marine areas through effectively and equitably managed, ecologically representative and well-connected systems of protected areas and other effective area-based conservation measures by 2020 (CBD, 2010). Meeting that target on time seems challenging despite recent substantial rises in MPA coverage (Bhola et al., 2016), as just three years ahead of the deadline, only $6.4 \%$ of the global ocean, including $15.9 \%$ of waters under national jurisdiction and $0.25 \%$ of waters in areas beyond national jurisdiction are covered by MPAs (UNEP-WCMC \& IUCN, 2017). Moreover, last year, the International Union for the Protection of Nature (IUCN) approved to call for ' $30 \%$ of each marine habitat' to be included in 'highly protected MPAs and OEABCMs' by 2030, with the ultimate aim of reaching 'a fully sustainable ocean, at least $30 \%$ of which has no extractive activities' (Davis, 2016).

Management is considered an essential factor for the ecological effectiveness of any protected area (Hockings et al., 2006; Bhola et al., 2016), more so in highly connected, heavily pressured and little enforced marine environments (Halpern et al., 2008; Mora \& Sale, 2011). Nevertheless, proper assessment of the effects of 
protection measures on biodiversity is costly, effortintensive and complex, as it very much depends on adequate semi-experimental designs that must account for natural populations' variability and a high number of confounders (García-Charton et al., 2004; Addison, 2011). Therefore, effectively protecting such huge amount of marine area seems a daunting task given the important costs of MPA designation and essential management activities such as surveillance or monitoring (Balmford et al., 2004; McCrea-Strub et al., 2011) and chronic underfunding of marine conservation activities (de Santo, 2013; Mazor et al., 2013) which currently result in most MPA area being insufficiently managed (Rodríguez-Rodríguez, in press). Moreover, there are little prospects that marine conservation funds are going to increase at all, let alone to keep pace with foreseen rapid MPA coverage growth (de Santo, 2013). Thus, scarce funds will have to render greater efficiency if some management is to be afforded to MPAs. As a result, rapid, cost-effective methods that are able to validly estimate conservation effectiveness are likely to become increasingly useful for the marine conservation community.

(M)PAs effective conservation and management is required by international policy (CBD, 2010) and, though a number of PA assessment techniques and evaluation frameworks have been developed (Leverington et al., 2010), very few have been yet applied to the marine environment, thus remaining a pending research task (Bhola et al., 2016). The most broadly used systems in terrestrial PAs are opinionbased (Ervin, 2003; Stolton et al., 2007) and, although they are of some use to identify major pressures, strengths and weaknesses to PAs, they have not shown accurate or precise enough to assess ecological effects (Carranza et al., 2014; Cook et al., 2014). Thus, there is the need for rapid assessment systems based on official statistics rather than (on in addition to) informed opinions, so at least precision can be ensured. Rodríguez-Rodríguez et al. (2016a) developed a Marine Protected Area Protection Framework (MaPAF) aimed at objectively assessing protection of (M)PAs based on indicators of legal and managerial protection and applied it to the Mediterranean MPA system. MPA protection was used as a surrogate for ecological effectiveness, although proper validation is needed.

In Spain, FRs were pioneering measures to improve the sustainability of the marine environment, with the first FR being designated in 1986 (Spanish Government, 1986). Though designated through the fisheries legislation and aimed at the enhancement of fishing resources and artisanal fisheries (Spanish Government, 2001), Spanish FRs have been historically considered the only MPA network in the country and included in national (García-Charton et al., 2004; Planes et al., 2006) and international MPA publications (Gabrié et al., 2012). Since 2010, they were officially included in the Spanish MPA Network (Spanish Government, 2010). They are generally considered ecologically effective, highly protected and well managed MPAs (García, 2010), although specific studies to assess their actual protection are scarce and opinion-based. Studies on FRs' ecological effects are more abundant, but they do not cover all FRs, are often site and feature-specific, and sometimes lack adequate controls (Planes et al., 2006).

In this study, the MaPAF (Rodríguez-Rodríguez et al., 2016a) was applied to assess the protection afforded to the Spanish FRN in order to identify legal and managerial strengths and weaknesses. The results on protection were compared with a quick assessment of the FRN's ecological effectiveness based on essential factors for the ecological effectiveness of MPAs (Edgar et al., 2014).

\section{Methods}

\subsection{Study area}

The FRN includes ten FRs which are managed by the Spanish Ministry of Agriculture, Fisheries, Food and the Environment alone or jointly with regional governments. They cover approximately 266,900 hectares of chiefly inshore area, distributed in zones of different legal stringency, and are located in three different marine ecoregions (Table 1).

\subsection{Protection assessment}

The MaPAF (Rodríguez-Rodríguez et al., 2016a) was applied to the Spanish FRN. The MaPAF assesses MPA protection through two sub-indices of equal value: legal protection (level of protection; LoP), valued from 1 point to 6 points, and management effort (sub-level of protection; SloP), valued from 0 points to 6 points. Both indices are divided in four headline indicators: legal designations and regulation stringency (for LoP); and enforcement and management planning (for SloP; Fig. 1). Table 2 shows how each headline indicator was measured and valued.

The FRN central managerial authority, the Fisheries Unit of the Spanish Ministry of Agriculture, Fisheries, Food and the Environment provided management effort data and the GIS layer with boundaries of the FRN. To assess the number of overlapping legal designations (valued from 1 to 3 points), the digital layers of all other MPA designations currently designated or proposed in Spain were downloaded from the Spanish Ministry of Agriculture, Fisheries, Food and the Environment's digital repository (Spanish Government, 2017). MPA designations included: 1) Special Areas of Conservation (SACs); 2) Sites of Community Importance (SCIs); 3) Special Protection Areas (SPAs); 4) Ramsar sites; 5) Biosphere Reserves; 6) Special Protection Areas of Mediterranean Importance (SPAMIs); 7) and Nationally designated MPAs or PAs with some marine area. All MPA layers were unioned and the resulting layer was clipped against the FR layer, counting legal designations on each protected polygon of the FRN. Finally, a weighted mean according to the proportion of each FR's 


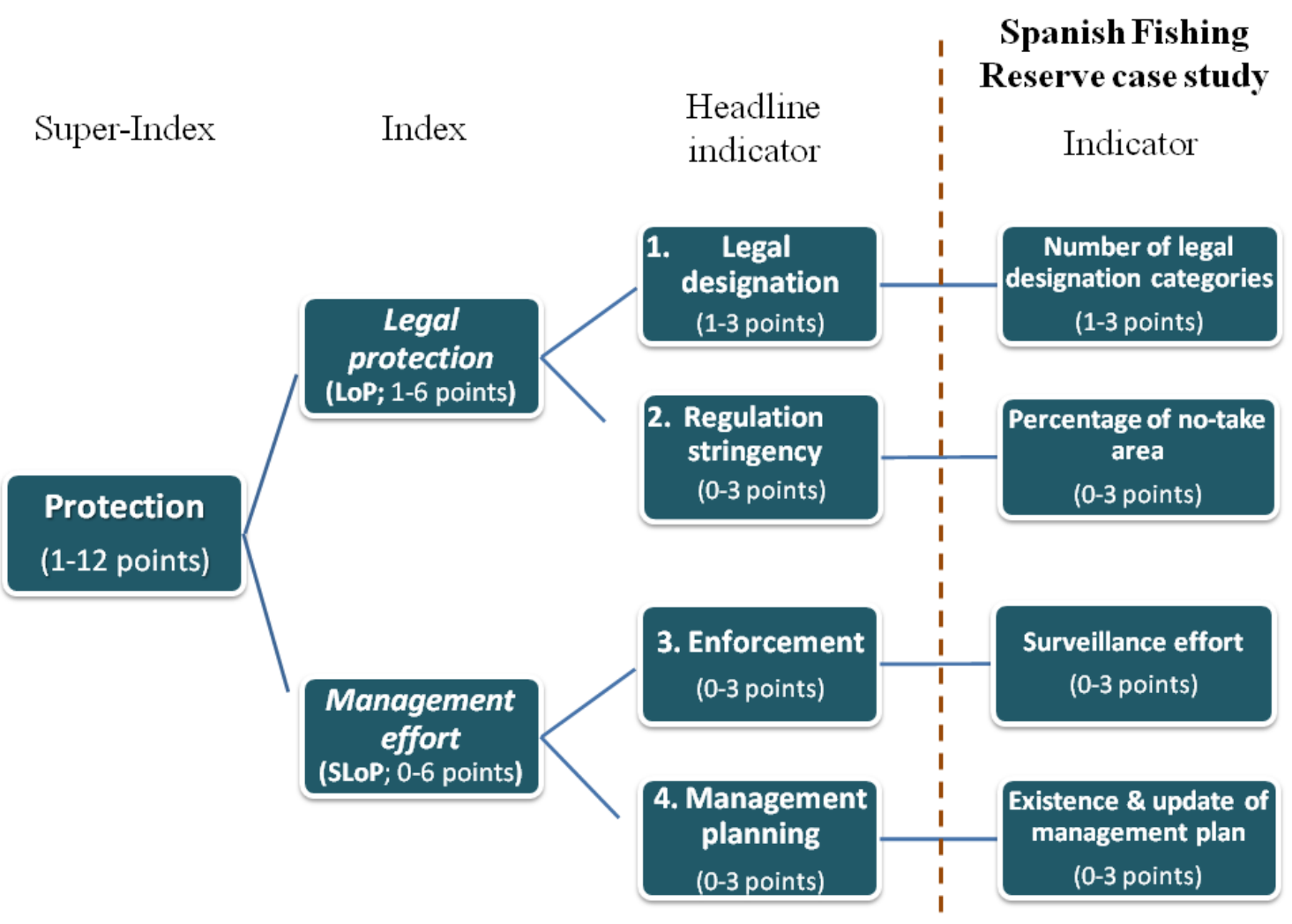

Fig. 1. Outline of the MaPAF and its application to the Spanish Fishing Reserve Network.

Table 1

Main characteristics of the Spanish Fishing Reserve Network

\begin{tabular}{l|c|c|l|l|l|}
\cline { 2 - 5 } $\begin{array}{l}\text { Fishing } \\
\text { Reserve }\end{array}$ & Designation & Area (ha.) & $\begin{array}{l}\text { No-take } \\
\text { area (ha.) }\end{array}$ & Management & Marine ecoregion* \\
\hline Tabarca & 1986 & 1,754 & 78 & Joint & Western Mediterranean \\
\hline Columbretes & 1990 & 5,493 & 3,112 & Spanish Ministry & Western Mediterranean \\
\hline Graciosa & 1995 & 70,439 & 1,076 & Joint & Azores, Canaries and Madeira \\
\hline Cabo de Palos & 1995 & 1,931 & 267 & Joint & Western Mediterranean \\
\hline Cabo de Gata & 1995 & 12,468 & 1,665 & Spanish Ministry & Alboran Sea \\
\hline La Restinga & 1996 & 1,180 & 237 & Joint & Azores, Canaries and Madeira \\
\hline Alborán & 1997 & 158,594 & 695 & Spanish Ministry & Alboran Sea \\
\hline Masía Blanca & 1999 & 457 & 43 & Spanish Ministry & Western Mediterranean \\
\hline La Palma & 2001 & 3,455 & 837 & Spanish Ministry & Azores, Canaries and Madeira \\
\hline Cala Rajada & 2007 & 11,285 & 2,000 & Joint & Western Mediterranean \\
\hline
\end{tabular}

*Based on the classification by Spalding et al. (2007) 
Table 2

Measurement, valuation and interpretation of MaPAF's headline indicators

\begin{tabular}{|c|c|c|c|}
\hline Headline indicator & Indicator & Valuation (points) & Interpretation \\
\hline \multirow[t]{3}{*}{ Legal designations } & Mean number of legal & $x<1.5 \rightarrow 1$ point & Low \\
\hline & designations $(x)$ & $1.5 \geq x \leq 2.5 \rightarrow 2$ points & Medium \\
\hline & & $x>2.5 \rightarrow 3$ points & High \\
\hline \multirow{4}{*}{$\begin{array}{l}\text { Regulation } \\
\text { stringency }\end{array}$} & Proportion of no-take & $y<10 \% \rightarrow 0$ points & Very low \\
\hline & area $(y)$ & $10 \% \leq y \leq 25 \% \rightarrow 1$ point & Low \\
\hline & & $26 \% \leq y \leq 50 \% \rightarrow 2$ points & Moderate \\
\hline & & $y>50 \% \rightarrow 3$ points & High \\
\hline \multirow[t]{4}{*}{ Enforcement } & Surveillance effort $(v)$ & $v \leq 0.99 \rightarrow 0$ points & Very low \\
\hline & & $1 \leq v \leq 1.98 \rightarrow 1$ point & Low \\
\hline & & $1.99 \leq v \leq 2.97 \rightarrow 2$ points & Moderate \\
\hline & & $v>2.97 \rightarrow 3$ points & High \\
\hline \multirow{4}{*}{$\begin{array}{l}\text { Management } \\
\text { planning }\end{array}$} & Existence and update of & No $w \rightarrow 0$ points & Very low \\
\hline & management plan $(w)$ & $w>10$ ys old $\rightarrow 1$ point & Low \\
\hline & & 10 ys $\leq w \leq 5$ ys $\rightarrow 2$ points & Moderate \\
\hline & & $w<5$ ys old $\rightarrow 3$ points & High \\
\hline
\end{tabular}

area covered by each number of legal designations was calculated. Regulation stringency was assessed as the proportion of no-take area relative to overall FR's area, and valued from 0 to 3 points.

To measure enforcement (valued from 0-3 points), a standardised surveillance effort index that added the hours of terrestrial and marine surveillance in each FR per year and divided it by each FR's area was produced. Mean surveillance effort (in hours / ha.) for the 20082015 period was calculated. Valuation thresholds were established according to data range's quartiles. Surveillance effort data for two FRs (Graciosa and Masía Blanca) was not provided, so its lowest value was conservatively assigned to both, because of existence of active management including surveillance boats. The Spearman rank order correlation test was used to check whether surveillance effort was related to FR's size, for $\alpha=0.05$, after checking the non-normality of variables. Management planning was assessed as the existence of updated management plans for each FR, and valued from 0-3 points. Each headline indicator was valued for integration in each sub-index by simple addition as shown in Table 2. Then, protection was assessed by summing the results of LoP and SloP.

\subsection{Assessment of ecological effectiveness}

To estimate the potential ecological effectiveness of the Spanish FRN, a rapid evaluation framework based on the five key factors for MPA effectiveness identified by Edgar et al. (2014) was developed: no-take area; enforcement; age; size; and degree of isolation. Such criteria have been used in recent studies on MPA ecological effectiveness (Giakoumi et al., 2017). Valuation thresholds were adapted from Edgar et al. (2014) when possible or from the MaPAF assesssment (Table 3). FRs' effectiveness was calculated summing the scores of each factor.

All calculations were done using Arc-GIS v. 10.3 in the ETRS 1989, UTM Zone 30 coordinate system and Microsoft Excel. 
Table 3

Measurement, valuation and interpretation of NEOLI's framework indicators

\begin{tabular}{|c|c|c|c|}
\hline Factor & Indicator & Valuation (points) & Interpretation \\
\hline \multirow[t]{4}{*}{ No-Take area } & Proportion of no-take & $y<10 \% \rightarrow 0$ points & Very low \\
\hline & area $(y)$ & $10 \% \leq y \leq 25 \% \rightarrow 1$ point & Low \\
\hline & & $26 \% \leq y \leq 50 \% \rightarrow 2$ points & Moderate \\
\hline & & $y>50 \% \rightarrow 3$ points & High \\
\hline \multirow[t]{4}{*}{ Enforcement } & Surveillance effort $(v)$ & $v \leq 0.99 \rightarrow 0$ points & Very low \\
\hline & & $1 \leq v \leq 1.98 \rightarrow 1$ point & Low \\
\hline & & $1.99 \leq v \leq 2.97 \rightarrow 2$ points & Moderate \\
\hline & & $v>2.97 \rightarrow 3$ points & High \\
\hline \multirow[t]{4}{*}{ Age } & Age of the fishing & $z<5$ ys old $\rightarrow 0$ points & Very low \\
\hline & reserve $(z)$ & 5 ys $\leq z \leq 9$ ys $\rightarrow 1$ point & Low \\
\hline & & 10 ys $\leq z \leq 15$ ys $\rightarrow 2$ points & Moderate \\
\hline & & $z<15$ ys old $\rightarrow 3$ points & High \\
\hline \multirow[t]{4}{*}{ Size } & Size of the fishing & $u<1 \mathrm{~km}^{2} \rightarrow 0$ points & Very low \\
\hline & reserve $(u)$ & $1 \mathrm{~km}^{2} \leq u \leq 10 \mathrm{~km}^{2} \rightarrow 1$ point & Low \\
\hline & & $10 \mathrm{~km}^{2} \leq u \leq 100 \mathrm{~km}^{2} \rightarrow 2$ points & Moderate \\
\hline & & $u>100 \mathrm{~km}^{2} \rightarrow 3$ points & High \\
\hline \multirow{4}{*}{$\begin{array}{l}\text { Degree of } \\
\text { isolation }\end{array}$} & Distance from the & $c=0 \mathrm{~km} \rightarrow 0$ points & Very low \\
\hline & coastline $(c)$ & $0 \mathrm{~km} \leq c<10 \mathrm{~km} \rightarrow 1$ point & Low \\
\hline & & $10 \mathrm{~km} \leq c \leq 50 \mathrm{~km} \rightarrow 2$ points & Moderate \\
\hline & & $c>50 \mathrm{~km} \rightarrow 3$ points & High \\
\hline
\end{tabular}

\section{Results}

\subsection{Protection assessment of the FRN}

\subsubsection{Legal protection}

Most FRN area is afforded one legal designation. However, the amount of FRN area that is afforded three or more legal designations exceeds 50\% (Table 4). Fig. 2 shows the number and geographic distribution of legal designations across the FRN.

The proportion of cumulative legal designations within FRs is shown in Appendix 1.

Of the approximately 267,000 hectares of the FRN, around 10,000 hectares, or $3.75 \%$, are fully no-take (Table 5). The only FR with greater amount of no-take area than multiple-use area was Columbretes FR.

\section{Table 4}

Area and proportion of the Fishing Reserve Network covered by cumulative legal designations

\begin{tabular}{c|c|r|}
\cline { 2 - 3 } $\begin{array}{c}\text { Number of legal } \\
\text { designations }\end{array}$ & Area (ha) & $\begin{array}{r}\text { Network } \\
\text { area (\%) }\end{array}$ \\
\hline 1 & 95,672 & 35.85 \\
\hline 2 & 36,318 & 13.61 \\
\hline 3 & 70,177 & 26.30 \\
\hline 4 & 43,121 & 16.16 \\
\hline 5 & 21,582 & 8.09 \\
\hline \multirow{2}{*}{ Total } & 266,870 & 100 \\
\cline { 2 - 3 } & &
\end{tabular}




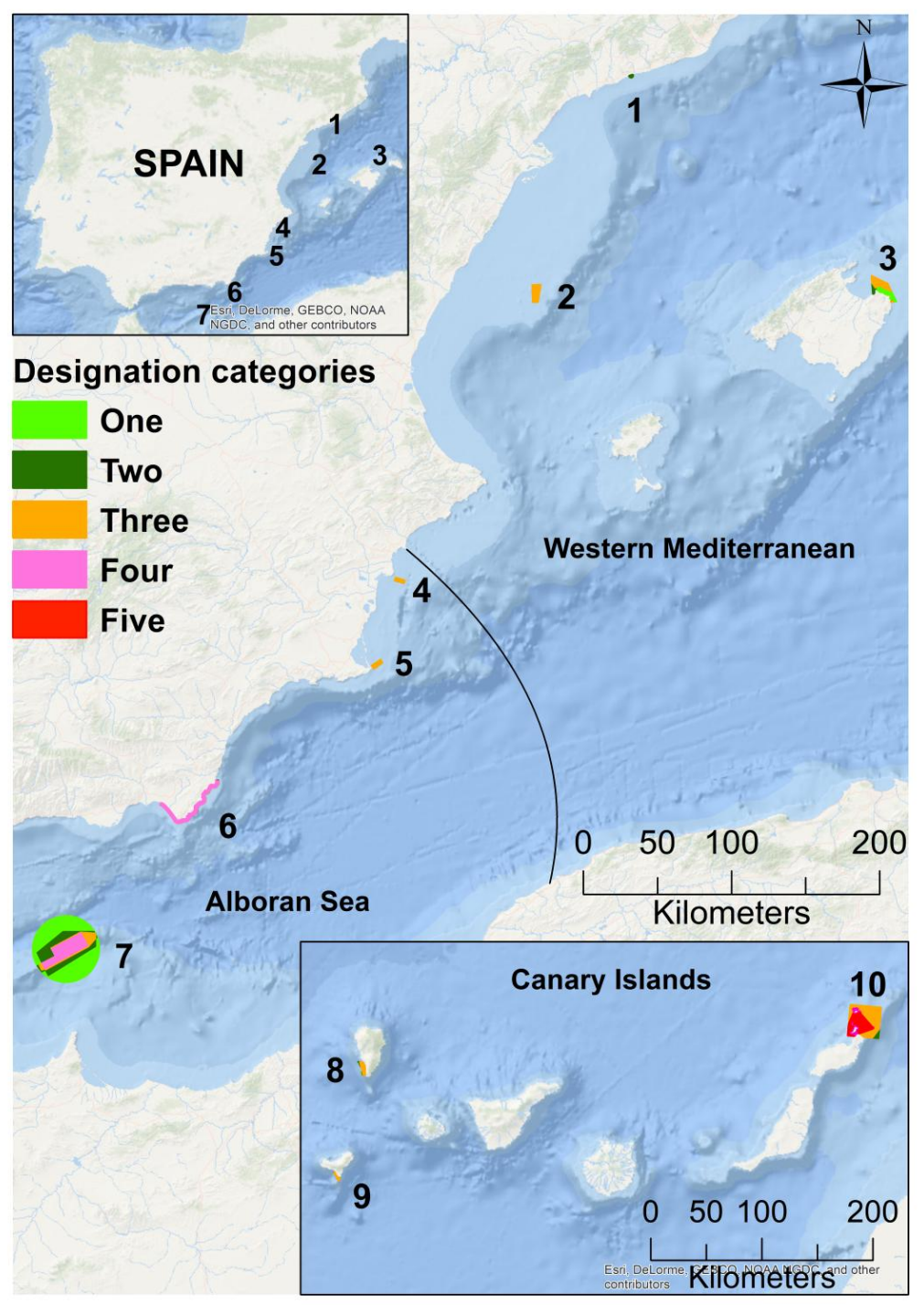

Fig. 2. Legal designations across the Spanish Fishing Reserve Network

1: Masía Blanca; 2: Columbretes; 3: Cala Rajada; 4: Tabarca; 5: Cabo de Palos; 6: Cabo de Gata; 7: Alborán; 8: La Palma; 9: La Restinga; 10: Graciosa

\subsubsection{Management effort}

Surveillance effort ranks from $3.97 \mathrm{~h} / \mathrm{ha}$.x year in La Restinga FR to $0.01 \mathrm{~h} /$ ha.x year in Alboran FR (Table 6). There was a very strong, negative correlation between surveillance effort and FR's size: $\left.r_{s(6)}=-0.83 ; p=0.01\right)$.

All FRs have management plans. For some FRs different activities are regulated in different norms. The oldest management plan dates 2000 and the newest, 2017 (Table 7).

\subsubsection{Overall protection}

The Spanish FRN has medium-high protection, averaging very similarly in LoP and SloP. The strongest contributor to protection is legal designations, whereas the weakest is legal stringency (Table 8). Columbretes FR and Cabo de Palos FR are the most protected FRs. Columbretes FR reaches has the greatest LoP, whereas Cabo de Palos is afforded the greatest managerial effort of the FRN. In contrast, lowly legally protected and managed Alboran FR ranks last in protection.

\subsection{Potential ecological effectiveness of the FRN}

The Spanish FRN is potentially moderately effective. Age is the factor contributing most positively to ecological effectiveness of the FRN whereas isolation is the factor contributing the least. Columbretes FR and Alboran FR were the most ecologically effective FRs, whereas Masía Blanca was the least ecologically effective (Table 9). 
Table 5.

Amount and proportion of no-take area across the Fishing Reserve Network

\begin{tabular}{lr|r|r|}
\cline { 2 - 4 } \multicolumn{1}{c|}{$\begin{array}{c}\text { Fishing } \\
\text { reserve }\end{array}$} & \multicolumn{1}{c|}{$\begin{array}{c}\text { Area (ha) } \\
\text { area (ha) }\end{array}$} & $\begin{array}{r}\text { No-Take } \\
\text { area (\%) }\end{array}$ \\
\hline Columbretes & 5,493 & 3,112 & 56.65 \\
\hline La Palma & 3,455 & 837 & 24.23 \\
\hline La Restinga & 1,180 & 237 & 20.08 \\
\hline Cala Rajada & 11,285 & 2,000 & 17.72 \\
\hline Cabo de Palos & 1,931 & 267 & 13.83 \\
\hline Cabo de Gata & 12,438 & 1,665 & 13.39 \\
\hline Masía Blanca & 457 & 43 & 9.41 \\
\hline Tabarca & 1,754 & 78 & 4.45 \\
\hline Graciosa & 70,439 & 1,076 & 1.53 \\
\hline Alborán & 158,594 & 695 & 0.44 \\
\hline NETWORK & 267,026 & 10,010 & 3.75 \\
\cline { 2 - 4 }
\end{tabular}

Table 6.

Surveillance effort and boats across the Fishing Reserve Network

\begin{tabular}{l|r|r|r|}
\cline { 2 - 4 } $\begin{array}{l}\text { Fishing } \\
\text { reserve }\end{array}$ & \multicolumn{1}{c|}{$\begin{array}{c}\text { Area } \\
\text { (ha.) }\end{array}$} & $\begin{array}{r}\text { Surveillance } \\
\text { effort (h/ha.) }\end{array}$ & \multicolumn{2}{|c|}{$\begin{array}{c}\text { Surveillance } \\
\text { boats }\end{array}$} \\
\hline La Restinga & 1,180 & 3.97 & 1 \\
\hline Tabarca & 1,754 & 2.92 & 3 \\
\hline Cabo de Palos & 1,931 & 1.57 & 3 \\
\hline La Palma & 3,455 & 1.28 & 2 \\
\hline Columbretes & 5,493 & 0.79 & 3 \\
\hline Cala Rajada & 11,285 & 0.15 & 2 \\
\hline Cabo de Gata & 12,468 & 0.15 & 2 \\
\hline Alborán & 158,594 & 0.01 & 3 \\
\hline Graciosa & 70,439 & & 1 \\
\hline Masía Blanca & 457 & & 2 \\
\cline { 2 - 4 } & & &
\end{tabular}

Table 7.

Existence and date of management plans across the Fishing Reserve Network

\begin{tabular}{|c|c|c|}
\hline $\begin{array}{l}\text { Fishing } \\
\text { reserve }\end{array}$ & $\begin{array}{l}\text { Management } \\
\text { plan }\end{array}$ & Date \\
\hline La Palma & Yes & $2001 ; 2002 ; 2010$ \\
\hline La Restinga & Yes & 1996, 2005 \\
\hline Graciosa & Yes & $\begin{array}{l}1995 ; 1999 ; 2000 ; 2001 ; \\
2003\end{array}$ \\
\hline Tabarca & Yes & $1986 ; 1988 ; 2000$ \\
\hline Alborán & Yes & $1998 ; 2001$ \\
\hline $\begin{array}{l}\text { Cabo de } \\
\text { Gata }\end{array}$ & Yes & 1995; 1996; 2001; 2011 \\
\hline $\begin{array}{l}\text { Cabo de } \\
\text { Palos }\end{array}$ & Yes & $\begin{array}{l}1995 ; 1999 ; 2000 ; 2001 ; \\
2002 ; 2017\end{array}$ \\
\hline Columbretes & Yes & $\begin{array}{l}1990 ; 2000 ; 2002 ; 2003 ; \\
2008 ; 2009\end{array}$ \\
\hline Cala Rajada & Yes & 2007 \\
\hline $\begin{array}{l}\text { Masía } \\
\text { Blanca }\end{array}$ & Yes & $\begin{array}{l}\text { 1999; 2000; 2001; 2004; } \\
2010,2016\end{array}$ \\
\hline
\end{tabular}

\section{Discussion}

\subsection{Protection of the FRN}

The Spanish FRN is moderately protected, both legally and managerially. In general, our findings reflect comparatively high protection of the FRN in the Mediterranean MPA context, to which most Spanish FRs belong, especially regarding managerial effort (Rodríguez-Rodríguez et al., 2016a). Our results are also akin to those by Rodríguez-Rodríguez et al., (2015a) in the English Channel, a similarly pressured marine environment (McClellan et al., 2014). Using an expertbased assessment approach, they ascertained medium protection of most Channel MPAs. However, our results on the Spanish FRN are generally less optimistic than those by García (2010). The finer, non-perceptual assessment done here is likely to explain most differences with her study. There are also some methodological explanations to this divergence. For instance, in this study the total area of Cabo de Gata FR more than doubled and Alboran FR's area almost increased by two orders of magnitude with regard to previous publications (García, 2010; Spanish Government, 2016). This resulted from the inclusion of interspersed marine nature park's area in the case of Cabo de Gata FR. This area was included as FR's area in 
Table 8

Valuation of protection across the Fishing Reserve Network using MaPAF. LoP: Level of protection; SloP: Sub-level of protection

\begin{tabular}{|c|c|c|c|c|c|c|c|}
\hline $\begin{array}{l}\text { Fishing } \\
\text { reserve }\end{array}$ & $\begin{array}{l}\text { Legal } \\
\text { designations }\end{array}$ & $\begin{array}{l}\text { Regulation } \\
\text { stringency }\end{array}$ & LoP & $\begin{array}{l}\text { Management } \\
\text { planning }\end{array}$ & Enforcement & SloP & Protection \\
\hline Columbretes & 3 & 3 & 6 & 2 & 1 & 3 & 9 \\
\hline Cabo de Palos & 3 & 1 & 4 & 3 & 2 & 5 & 9 \\
\hline La Palma & 3 & 1 & 4 & 2 & 2 & 4 & 8 \\
\hline La Restinga & 3 & 1 & 4 & 1 & 3 & 4 & 8 \\
\hline Cabo de Gata & 3 & 1 & 4 & 2 & 1 & 3 & 7 \\
\hline Tabarca & 3 & 0 & 3 & 1 & 3 & 4 & 7 \\
\hline Cala Rajada & 2 & 1 & 3 & 2 & 1 & 3 & 6 \\
\hline Masía Blanca & 2 & 0 & 2 & 3 & 1 & 4 & 6 \\
\hline Graciosa & 3 & 0 & 3 & 1 & 1 & 2 & 5 \\
\hline Alborán & 2 & 0 & 2 & 1 & 1 & 2 & 4 \\
\hline $\begin{array}{l}\text { NETWORK } \\
\text { MEAN }\end{array}$ & 2.7 & 0.8 & 3.5 & 1.8 & 1.6 & 3.4 & 6.9 \\
\hline
\end{tabular}

Table 9

Valuation of potential ecological effectives across the Fishing Reserve Network using the NEOLI framework

\begin{tabular}{l|l|l|l|l|l|l|}
\cline { 2 - 7 } Fishing reserve & No-Take & Enforcement & Age & Size & Isolation & Effectiveness \\
\hline Columbretes & 3 & 1 & 3 & 2 & 2 & $\mathbf{1 1}$ \\
\hline Alborán & 0 & 1 & 3 & 3 & 3 & $\mathbf{1 0}$ \\
\hline Tabarca & 0 & 3 & 3 & 2 & 1 & $\mathbf{9}$ \\
\hline Cabo de Gata & 1 & 1 & 3 & 3 & 0 & $\mathbf{8}$ \\
\hline Cabo de Palos & 1 & 2 & 3 & 2 & 0 & $\mathbf{8}$ \\
\hline La Palma & 1 & 2 & 3 & 2 & 0 & $\mathbf{8}$ \\
\hline La Restinga & 1 & 3 & 3 & 1 & 0 & $\mathbf{8}$ \\
\hline Cala Rajada & 1 & 1 & 2 & 3 & 0 & $\mathbf{7}$ \\
\hline Graciosa & 0 & 1 & 3 & 3 & 0 & $\mathbf{7}$ \\
\hline Masía Blanca & 0 & 1 & 3 & 1 & 0 & $\mathbf{5}$ \\
\hline $\begin{array}{l}\text { NETWORK } \\
\text { MEAN }\end{array}$ & 0.8 & 1.6 & 2.9 & 2.2 & 0.6 & 8.1
\end{tabular}


the GIS layer provided by the FRN's managers but not in related publications. In the case of Alboran FR, previous publications did not account for the large, nationally designated peripheral fisheries restricted area (of approx. 157.000ha.) adjacent to the FR and subject to specific fishing regulations (Spanish Government, 1998). Thus, we think that this study shows a more accurate picture of the FRN's design and protection. Those updates affected the two area-related headline MaPAF indicators and resulted in much lower surveillance effort in both FRs and, provided that all this 'new' area is multiple-use, it also resulted in substantially lower regulation stringency for both.

The Spanish FRN has a high degree of legal designation overlap which should theoretically confer greater protection than single designations (RodríguezRodríguez et al., 2016a). However, no-take zones allowing only for scientific research cover a small fraction of the FRN network area, whereas most of it is multiple-use. Positive ecological effects from small notake zones have been reported (Rife et al., 2013). However, the current no-take proportion in the FRN will probably result most insufficient soon in view of oncoming stricter protection targets at 30\% (Davis, 2016). In FRN's multiple-use zones, different human activities of varying degrees of environmental impact are allowed with some restrictions: artisanal fishing, scuba diving and recreational fishing are the most common ones (Spanish Government, 2016). Such fishing activities can exert considerable pressure on some biological resources and are suggested to be responsible for the low effectiveness of multiple-use MPAs or zones compared to marine reserves or no-take zones (Planes et al., 2006; Lester \& Halpern, 2008).

Regarding legal MPA coverage, Spain has already exceeded current international targets by 2020 in inshore and offshore waters (Rodríguez-Rodríguez et al., 2016b). As a result, the country's MPA network can be considered close to completeness, with no massive additions expected in the near future. However, foreseeable oncoming MPA coverage and stringency targets are likely to force the country to expand its MPA legal and managerial effort, including a much greater proportion of no-take area and managed area (Davis, 2016), as now most of the Spanish MPA network is multiple-use and unmanaged (Rodríguez-Rodríguez et al., 2016a).

Management effort of the Spanish FRN is generally greater than in Mediterranean MPAs, especially for management planning (Rodríguez-Rodríguez et al., 2016a). Cullis-Suzuki \& Pauly (2010) also found relatively good managerial performance of Spanish MPAs (by that time, entirely FRs) in a global context using another indicator of managerial effort: investment in MPAs on running or maintenance costs. García (2010) similarly states favourable perception on existing management means and infrastructures by FRs' managers and 24/7 surveillance all the year through in seven FRs in 2010. However accurate that statement may be, the official FRN managers' data does not reflect spatial or temporal distribution of surveillance effort.

The commonest stated pressure by FRs' managers was poorly practiced fishing (either industrial, recreational or artisanal fishing; García, 2010), which largely coincide with the views of Mediterranean MPA managers who considered artisanal and recreational fishing the main pressures to their MPAs (Gabrié et al., 2012). Other stated pressures by Spanish FRs' managers included boat anchoring, illegal extractive activities, waste spills from recreational boats, infrastructure and urban development, introduction of non-local species, and public use (García, 2010). Thus, the majority of common pressures in the FRN can be tackled by FRs' managers, although other important pressures to marine environments such as ocean warming or pollution (Halpern et al., 2008) are largely outside their means and scope (Rodríguez-Rodríguez et al., 2015b). In terms of sea surveillance (boat density), Spanish FRs are within the minority of Mediterranean MPAs with some boats for surveillance, but their boat-to-area ratio is low (Rodríguez-Rodríguez et al., 2016a).

\subsection{Potential ecological effectiveness of the FRN}

Overall, the FRN was moderately to highly effective as assessed here. Only one FR was assessed as little ecologically effective. A bibliographic review found general positive ecological effects of five FRs on fish and benthic fauna abundance, density and/or biomass compared to unprotected sites: Cabo de Palos FR, Tabarca FR, Columbretes FR, Graciosa FR, and Restinga FR (Planes et al., 2006). They also found greater effectiveness in their no-take zones than in the FRs' multiple-use zones. Their study partially validated the results shown here by stating the comparatively low effectiveness of Graciosa FR. In another study comparing ecological effects of four Mediterranean MPAs that included three FRs (Cabo de Gata, Cabo de Palos and Columbretes), García-Charton et al. (2004) similarly found generally higher average values of total abundance and biomass, species richness and abundance, and biomass of different target species inside MPAs than in unprotected sites, although they highlighted the important effect of habitat dissimilarity between cases and controls and thus, the limited validity of their comparisons. Selecting adequate controls is as essential as challenging for valid semi-experimental studies on MPA effectiveness (Addison, 2011).

There was low correspondence between FRs' ranking by protection and by potential ecological effectiveness even though both indices shared a remarkable percentage of indicators. Previous studies have neither been able to link protection intensity to MPAs' ecological outcomes (Rodríguez-Rodríguez et al., 2015a) beyond dual multiple-use versus no-take comparisons (Sciberras et al., 2015). It is worth noting the limited geographic representation of MPAs in the study by Edgar et al. (2014) from which the NEOLI framework was derived, with half of their 87 MPA sample from Australia and New Zealand. This may have 
biased their results to regional-specific contexts and effectiveness factors.

\subsection{Individual performance of FRs}

Columbretes FR ranked the first, both in terms of protection and of potential ecological effectiveness. It meets most legal and bio-physical characteristics for ecological effectiveness (Edgar et al., 2014): it has medium size $(5,500$ ha. $), 57 \%$ of which is no-take; it is 27 years old; and it is located more than $45 \mathrm{~km}$ from the coastline. It also has a reasonably updated management plan. García (2010) also pointed to comparatively good local stakeholder participation in the management of the FR. Columbretes FR's main weakness comes from low surveillance effort. In their study, García-Charton et al. (2004) found generally better values on number of species, mean species richness, mean abundance, mean biomass and species diversity for Columbretes FR than for some control sites, although they did not found consistent better performance than two other FRs: Cabo de Gata FR and Cabo de Palos FR.

In turn, Alboran FR was the least protected FR. It scores very lowly in regulation stringency and lowly in both management indicators. It, however, ranked second in potential ecological effectiveness. Alboran FR has a number of characteristics that make it prone to ecological effectiveness (Edgar et al., 2014). Firstly, it is, together with Columbretes FR, the only offshore FR. This may prevent most pressures which originate in or concentrate along the coast (Halpern et al., 2008; Rodríguez-Rodríguez et al., 2015b) and reduce the need for increased protection, although that remains to be studied, as important threats to biodiversity such as bottom trawling or pollution from abundant ship traffic in the area can occur. Secondly, it is an old, well established FR with 20 years of age. Thirdly, it is the biggest FR in the FRN. According to García (2010), the most pressured FRs were Cabo de Gata FR, Tabarca Island FR and Alboran Island FR, respectively. The main pressures in Cabo de Gata FR were public use and industrial fishing. In the case of Tabarca Island FR, the most serious pressures were recreational fishing and pollution from liquid spills, whereas all main pressures in Alboran FR related to fishing, especially industrial fishing (García, 2010).

The relatively poor legal and managerial performance of Alboran FR and Graciosa FR were related to their great size, which affected three of the four MaPAF indicators. Small, coastal, mostly multipleuse and lowly enforced Masía Blanca scored the lowest in potential ecological performance, followed by coastal, huge, but little stringent Graciosa FR. Those results are partially coincident with those of the perceptional study by García (2010) that stated that Tabarca Island FR and Graciosa FR were the FRs with the poorest managerial outcomes. The little surveillance effort in Graciosa FR was already pointed out more than a decade ago and was suggested responsible for the reduced ecological effects of the FR and its no-take zone due to poaching (Planes et al., 2006).

\section{Conclusions}

The Spanish FRN is moderately protected, both in legal and managerial terms, and has moderate-to-high potential ecological effectiveness. It is better protected than most Mediterranean MPAs, although greater legal and managerial effort should be done to ensure their ecological effectiveness. More precisely, most effective no-take zones should be considerably expanded throughout the FRN in light of new oncoming international marine protection targets. Nevertheless, this expansion should consider other MPAs making the Spanish MPA network and MPAs-to-be, be gradual and include local stakeholders as much as possible in order to avoid pervasive social or economic effects. Also, greater managerial effort, chiefly in terms of surveillance, should be provided to currently undersurveilled FRs. Among those, important effort should be put in ensuring adequate levels of surveillance in the biggest FRs: Alboran FR and Graciosa FR. Complementary studies on ecological features and pressures should be developed to properly allocate further legal or managerial resources. Nevertheless, the Spanish FRN is comparatively well protected so additional legal or managerial resources, if any, would most likely be more necessary in other newly designated MPAs of the rapidly expanding MPA network of the country (Bhola et al., 2016; Rodríguez-Rodríguez et al., 2016b) which still lacks legal protection and, especially, managerial effort.

\section{Acknowledgements}

I would like to thank Silvia Revenga, José Carlos Mendoza and Juan Carlos Jorquera, from the Spanish Ministry of Agriculture \& Fishing, Food and the Environment, for providing data on management effort and assisting in interpreting the results. DRR was funded for this study by the Spanish Ministry of Economy, Industry and Competitiveness in the framework of the SOSTPARK project (CSO2014-54611-JIN). 
Appendix 1

Cumulative legal designations in Spanish Fishing Reserves

\begin{tabular}{|c|c|c|c|c|}
\hline Fishing Reserve & Area (ha) & $\begin{array}{l}\text { Number of } \\
\text { designations }\end{array}$ & $\begin{array}{l}\text { Area covered by legal } \\
\text { designation class (ha) }\end{array}$ & $\begin{array}{l}\text { Proportion of legal designation } \\
\text { class in fishing reserve }(\%)\end{array}$ \\
\hline Cabo de Palos & 1,931 & 2 & 171.62 & 8.89 \\
\hline Cabo de Palos & 1,931 & 3 & $1,758.78$ & 91.07 \\
\hline Alborán & 158,594 & 1 & $90,783.20$ & 57.24 \\
\hline Alborán & 158,594 & 2 & $31,394.80$ & 19.80 \\
\hline Alborán & 158,594 & 3 & $10,978.50$ & 6.92 \\
\hline Alborán & 158,594 & 4 & $25,436.60$ & 16.04 \\
\hline Tabarca & 1,379 & 2 & 7.23 & 0.52 \\
\hline Tabarca & 1,379 & 3 & $1,372.03$ & 99.48 \\
\hline Graciosa & 70,784 & 1 & 25.22 & 0.04 \\
\hline Graciosa & 70,784 & 2 & $2,679.49$ & 3.79 \\
\hline Graciosa & 70,784 & 3 & $40,756.90$ & 57.58 \\
\hline Graciosa & 70,784 & 4 & $5,739.49$ & 8.11 \\
\hline Graciosa & 70,784 & 5 & $21,582.00$ & 30.49 \\
\hline La Restinga & 912 & 2 & 60.36 & 6.62 \\
\hline La Restinga & 912 & 3 & 850.68 & 93.32 \\
\hline Columbretes & 5,490 & 3 & $5,489.80$ & 99.99 \\
\hline Masía Blanca & 446 & 1 & 1.45 & 0.33 \\
\hline Masía Blanca & 446 & 2 & 444.58 & 99.67 \\
\hline Cabo de Gata & 12,468 & 1 & 161.13 & 1.29 \\
\hline Cabo de Gata & 12,468 & 2 & 234.57 & 1.88 \\
\hline Cabo de Gata & 12,468 & 3 & 126.50 & 1.01 \\
\hline Cabo de Gata & 12,468 & 4 & $11,945.30$ & 95.81 \\
\hline Cala Rajada & 11309.90 & 1 & $4,638.79$ & 41.02 \\
\hline Cala Rajada & 11309.90 & 2 & 904.79 & 8.00 \\
\hline Cala Rajada & 11309.90 & 3 & $5,765.56$ & 50.98 \\
\hline La Palma & 3560.96 & 1 & 61.95 & 1.74 \\
\hline La Palma & 3560.96 & 2 & 420.49 & 11.81 \\
\hline La Palma & 3560.96 & 3 & $3,078.09$ & 86.44 \\
\hline
\end{tabular}

\section{References}

Addison, P. 2011. A global review of long-term Marine Protected Area monitoring programmes: The application of a good framework to marine biological monitoring. Volume 1: Main Report. JNCC Report No. 455. Joint Nature Conservation Committee, Peterborough. Available online from:
http://jncc.defra.gov.uk/pdf/jncc455_Vol1_web.pdf [Accessed 07/11/2017]

Balmford, A., Gravestock, P., Hockley, N., McClean, C.J. \& Roberts, C.M. 2004. The worldwide costs of marine protected areas. PNAS, 101(26): 9694-9697.

Bhola, N., Juffe-Bignoli, D., Burguess, N., Sandwith, T. \& Kingston N. (Eds.) 2016. Protected Planet Report 2016. How protected areas contribute to achieving global targets 
for biodiversity. UNEP-WCMC and IUCN, Cambridge and Gland.

Carranza, T., Manica, A., Kapos, V. \& Balmford, A. 2014. Mismatches between conservation outcomes and management evaluation in protected areas: a case study in the Brazilian Cerrado. Biological Conservation, 173: 1016

CBD, Convention on Biological Diversity. 2010. Convention. Strategic Plan 2011-2020. Aichi Biodiversity Targets. https://www.cbd.int/sp/targets/ [Accessed 02/11/2017]

Cook, C.N., Carter, R.W., Hockings, M. 2014. Measuring the accuracy of management effectiveness evaluations of protected areas. Journal of Environmental Management, 139:164-171.

Cullis-Suzuki, S. \& Pauly, D. 2010. Marine Protected Area costs as "beneficial" fisheries subsidies: a global evaluation. Coastal Management, 38(2): 113-121.

Davis, J. 2016. IUCN Members Approve 30\%-by-2030 Goal for MPAs - Most ambitious target so far for MPA coverage. MPA News, 18(1): 2-3.

Day, J., Dudley, N., Hockings, M., Holmes, G., Laffoley, D., Stolton, S. \& Wells, S. 2012. Guidelines for applying the IUCN Protected Area Management Categories to Marine Protected Areas. IUCN, Gland.

Edgar, G.J.; Stuart-Smith, R.D.; Willis, T.J., Kininmonth, S. et al. 2014. Global conservation outcomes depend on marine protected areas with five key features. Nature, 506 216-20.

Ervin, J. 2003. Rapid Assessment and Prioritization of Protected Areas Management (RAPPAM) Methodology. WWF, Gland.

Gabrié, C., Lagabrielle, E., Bissery, C., Crochelet, E. et al., 2012. The Status of Marine Protected Areas in the Mediterranean Sea. MedPAN \& CAR/ASP. MedPAN Collection. MedPAN, Hyères, France.

García, L.S. 2010. Caso de aplicación de la metodología RAPPAM a la Red de Reservas Marinas de España. Fundación Interuniversitaria Fernando González Bernáldez, Madrid.

https://www.uam.es/otros/fungobe/doc/GarciaCorral2010 MetodologiaRAPPAMReservasMarinas.pdf [Accessed 30/11/2017]

García-Charton, J.A., Pérez-Ruzafa, A., Sánchez-Jerez, P., Bayle-Sempere, J.T., Reñones, O. \& Moreno, D. 2004 Multi-scale spatial heterogeneity, habitat structure, and the effect of marine reserves on Western Mediterranean rocky reef fish assemblages. Marine Biology, 144: 161-182.
Giakoumi, S., Scianna, C., Plass-Johnson, J., Micheli, F. et al. 2017. Ecological effects of full and partial protection in the crowded Mediterranean Sea: a regional meta-analysis. Scientific Reports 7, Article number: 8940 doi:10.1038/s41598-017-08850-w

Halpern, B.S., Walbridge, S., Selkoe, K.A., Kappel, C.V. et al. 2008. A global map of human impact on marine ecosystems. Science, 319(5865): 948-952.

Hockings, M., Stolton, S., Leverington, F., Dudley, N. \& Courrau, J. 2006. Evaluating Effectiveness: A framework for assessing management effectiveness of protected areas. 2nd Edition. IUCN, Gland and Cambridge.

Lester, S.E. \& Halpern, B.S. 2008. Biological responses in marine no-take reserves versus partially protected areas. Marine Ecology Progress Series, 367: 49-56.

Leverington, F., Lemos, K., Courrau, J., Pavese, H. et al. 2010. Management Effectiveness Evaluation in Protected Areas - A Global Study. University of Queensland, Brisbane.

Mazor, T., Possingham, H.P. \& Kark, S. 2013.

Collaboration among countries in marine conservation can achieve substantial efficiencies. Diversity \& Distributions, 19(11): 1380-1393.

McClellan, C.M., Brereton, T., Dell'Amico, F., Johns, D.G., et al. 2014. Understanding the distribution of marine megafauna in the English Channel Region: identifying key habitats for conservation within the busiest seaway on Earth. PloS One 9 (2), e89720. http://dx.doi.org/10.1371/journal.pone.0089720.

McCrea-Strub, A., Zeller, D., Sumaila, U.R., Nelson, J., Balmford, A. \& Pauly, D. 2011. Understanding the cost of establishing marine protected areas. Marine Policy, 35: 19.

Mora, C. \& Sale, P.F. 2011. Ongoing global biodiversity loss and the need to move beyond protected areas: a review of the technical and practical shortcomings of protected areas on land and sea. Marine Ecology Progress Series, 434: 251-266.

Planes S., García-Charton J.A. \& Pérez-Ruzafa A. (Coord.). 2006. Ecological effects of AtlantoMediterranean Marine Protected Areas in the European Union. EMPAFISH Project, Booklet $\mathrm{n}^{\circ} 1.158 \mathrm{pp}$. http://www.um.es/empafish/files/WP1\%20Booklet.pdf [Accessed 30/11/2017]

Rife, A.N., Aburto-Oropeza, O., Hastings, P.A., Erisman, B., Ballantyne, F., Wielgus, J., Sala, E. \& Gerber, L. 2013 Long-term effectiveness of a multi-use marine protected area on reef fish assemblages and fisheries landings. Journal of Environmental Management, 117: 276-283. 
Rodríguez-Rodríguez, D., Sciberras, M., Foster, N.L. \& Attrill, M.J. 2015a. Status of management effort in 153 marine protected areas across the English Channel. Marine Pollution Bulletin, 94: 168-175.

Rodríguez-Rodríguez, D., Sánchez-Espinosa, A., Schröder, C., Abdul Malak, D. \& Rodríguez, J. 2015b. Cumulative pressures and low protection: a concerning blend for Mediterranean MPAs. Marine Pollution Bulletin, 101: 288-295.

Rodríguez-Rodríguez, D., Rodríguez, J. \& Abdul Malak, D. 2016a. Development and testing of a new framework for rapidly assessing legal and managerial protection afforded by marine protected areas: Mediterranean Sea case study. Journal of Environmental Management, 167: 29-37.

Rodríguez-Rodríguez, D., Rodríguez, J., Abdul Malak, D., Nastasi, A. \& Hernández, P. 2016b. Marine protected areas and fisheries restricted areas in the Mediterranean: assessing "actual" marine biodiversity protection coverage at multiple scales. Marine Policy, 64: 24-30.

Rodríguez-Rodríguez, D. In press. Marine protected areas: attempting the sustainability of the seas. In Sheppard, C. (Ed.) The World's Seas.

Santo (de), E.M. 2013. Missing marine protected area (MPA) targets: How the push for quantity over quality undermines sustainability and social justice. Journal of Environmental Management, 124: 137-146.

Sciberras, M., Jenkins, S.R., Mant, R., Kaiser, M.J., Hawkins, S.J. \& Pullin, A.S. 2015. Evaluating the relative conservation value of fully and partially protected marine areas. Fish and Fisheries, 16: 58-77.

Spalding, M.D., Fox, H.E., Allen, G.R., Davidson, N. et al. 2007. Marine ecoregions of the world: a

bioregionalization of coastal and shelf areas. Bioscience, 57: 573-583.

Spanish Government. 1986. Orden de 4 de abril de 1986 por la que se establece una reserva marina en la Isla de Tabarca. Boletín Oficial del Estado, 112: 16769. https://www.boe.es/boe/dias/1986/05/10/pdfs/A1676916769.pdf [Accessed 30/11/2017]
Spanish Government. 1998. ORDEN de 8 de septiembre de 1998 por la que se establece una reserva marina y una reserva de pesca en el entorno de la isla de Alborán y se regula el ejercicio de la pesca en los caladeros adyacentes. Boletín Oficial del Estado, 233: 32541-32542.

http://www.boe.es/boe/dias/1998/09/29/pdfs/A3254132542.pdf [Accessed 30/11/2017]

Spanish Government. 2001. Ley 3/2001, de 26 de marzo, de Pesca Marítima del Estado. Boletín Oficial del Estado: 75: 11509-11532.

https://www.boe.es/boe/dias/2001/03/28/pdfs/A1150911532.pdf [Accessed 30/11/2017]

Spanish Government. 2010. Ley 41/2010, de 29 de diciembre, de protección del medio marino. Boletín Oficial del Estado: 317: 108464-108488.

https://www.boe.es/boe/dias/2010/12/30/pdfs/BOE-A2010-20050.pdf [Accessed 30/11/2017]

Spanish Government. 2016. Red de Reservas Marinas. Más de 30 años protegiendo nuestros mares. Ministerio de Agricultura y Pesca, Alimentación y Medio Ambiente. http://www.mapama.gob.es/es/ceneam/recursos/pagweb/red-reservas-marinas.aspx [Accessed 30/11/2017]

Spanish Government. 2017. Ministerio de Agricultura y Pesca, Alimentación y Medio Ambiente. Cartografía y SIG. Infraestructura de Datos Espaciales-IDE. Descargas del Área de Actividad de Biodiversidad. Espacios protegidos y/o de interés.

http://www.mapama.gob.es/es/cartografia-ysig/ide/descargas/biodiversidad/default.aspx [Accessed 14/11/2017]

Stolton, S., Hockings, M., Dudley, N., MacKinnon, K., Whitten, T. \& Leverington, F. 2007. Reporting Progress in Protected Areas. A Site Level Management Effectiveness Tracking Tool (2nd Ed.). World Bank/WWF Forest Alliance and WWF, Gland.

http://assets.panda.org/downloads/mett2_final_version_jul y_2007.pdf [Accessed 30/11/2017]

UNEP-WCMC \& IUCN. 2017. Marine Protected Planet [November, 2017]. UNEP-WCMC and IUCN, Cambridge. Available online from: www.protectedplanet.net [Accessed 07/11/2017] 